\title{
バインダーピグメントラテックスの塗工紙への適用
}

日本ゼオン株研究開発センター 宮本健三, 原田幸一, 関矢正良

\section{The application of Binder-pigment latex for coated paper}

\author{
Kenzo Miyamoto, Kooichi Harada and Masayoshi Sekiya \\ Research \& Development Center Nippon Zeon Co., Ltd.
}

\begin{abstract}
A binder-pigment latex with a unique core-shell structure has dual functions of plastic pigment as well as binder. The cost of coating compositions containing the binder-pigment latex is less than that of the plastic pigment. Because, the amount of a conventional latex is reduced due to the dual functions.

The coatings containing the binder-pigment latex showed high gloss, brightness, opacity and ink receptivity. Furthermore, the binder-pigment latex improved not only the glueability and blister -pack property of the coated boards in the practical applications but also missing dots in the gravure printing.

The cost of coatings was reduced by the optimization of the inorganic pigment composition and the coating amount.
\end{abstract}

Keywords : Binder pigment latex, Core-shell structure, Plastic pigment, Coated paper, Coated board, Gloss, Brightness, Ink receptivity, Blister-pack, Gravure

\section{1.はじめに}

顔料塗工紙に用いられる白色顔料のほとんどはクレ イ, 炭酸カルシウム, チタン白, サチン白などの無機 顔料である。これらの無機顔料はそれぞれ塗工紙の艶 や白さなどの光学的特性を付与するために有効であり， かつ必須である。一方，ポリスチレンなどの合成高分 子樹脂エマルジョンを顔料として用いる有機顔料 (プ ラスチックピグメント）が塗工紙の軽量化や高光沢の 付与を目的として開発されてきたが, 一般の無機顔料 に比して高価格であるため, その使用は一部にとど まっている。さらに近年, プラスチックピグメントの 機能にバインダーの機能を付与し, コスト上の欠点を 軽減したバインダーピグメントラテックスが開発され, 特に塗工板紙分野でその使用が拡大している。

本稿ではバインダーピグメントラテックスの特性と

本稿の一部は第 54 回紙パルプ研究発表会 (1987 年 6 月）で発表した。
実機適用例について報告する。

2. バインダーピグメントラテックス

プラスチックピグメントとして最も一般的であるの は粒子径 $0.2 \sim 0.5 \mu \mathrm{m}$ のポリスチレンラテックスで ある。ポリスチレンの比重は 1.05 でカオリナイトクレ イの比重 2.58 の半分以下であり, 軽量化に有効であ る。ポリスチレンの屈折率は 1.59 でカオリナイトクレ イの屈折率 1.57 と同等であり, また, サブミクロン オーダーの微粒子であるため光を拡散させる効果が大 きく, 白色度や不透明度を向上させる ${ }^{12) 31}$ 。さらに, 熱 可塑性であるため無機顔料よりカレンダー効果が出易

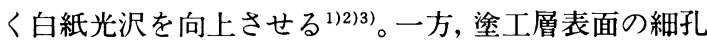
も多く，孔径分布も均一であるためインク受理性など の印刷適性も向上する ${ }^{233)}$ 。

バインダーピグメントラテックスはこれらのプラス チックピグメントの特長を保持し, さらにバインダー 機能を併有させたものである ${ }^{4)}$ 。 バインダーピグメントラテックスは図 1 に示した粒 


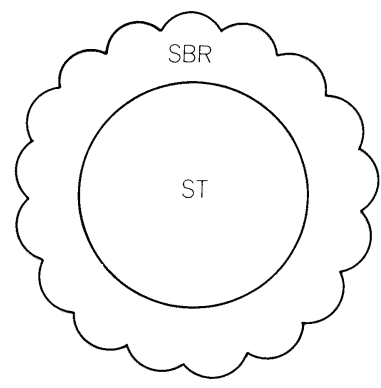

図 1 バインダーピグメントラテックスの粒子構造 モデル
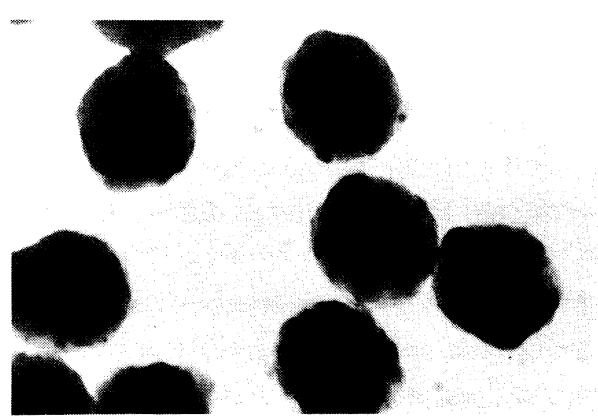

$1 \mu$

写真 1 バインダーピグメントラテックスの透過型 電子顕微鏡写真

子構造モデルを有する特殊な二層構造ラテックスであ る。

二層構造の芯部はポリスチレンで構成されており， 殼部はスチレンーブタジエン共重合体で構成されてい る。芯部（ポリスチレン）がプラスチックピグメント としての機能を有し, 款部（スチレンーブタジエン共 重合体）がバインダーとしての機能を有している。

個々のラテックス粒子が顔料機能とバインダー機能 を併有している点に大きな特徴がある。

写真 1 にバインダーピグメントラテックスの透過型 電子顕微鏡写真を示した。

バインダーピグメントラテックスとしては日本ゼオ ン粕より Nipol Lx 407 BP が上市されている。

\section{3. バインダーピグメントラテックスの特性}

モデル配合を用いてバインダーピグメントラテック スの特性を検討した。

\section{1 プラスチックピグメントとの比較}

カオリナイトクレイ単独配合, プラスチックピグメ ント使用配合，バインダーピグメントラテックス使用 配合の 3 配合を塗工板紙に適用し評価した。

表 1 に配合処方と評価結果を，表 2 に塗工紙作成方 法および塗工紙評価方法を示した。
表 1 バインダーピグメントラテックスとプラス チックビグメントの塗1板紙铗価比較

\begin{tabular}{|c|c|c|c|c|}
\hline & & A & B & $\mathrm{C}$ \\
\hline \multirow{5}{*}{ 配 } & \multirow{3}{*}{$\begin{array}{l}\text { 一級クレイ } \\
\text { プラスチックビグメント } \\
\text { バインダービグメントラテ } \\
\text { ックス }\end{array}$} & $100^{\circ}$ & 90 & 90 \\
\hline & & 0 & 10 & 0 \\
\hline & & 0 & 0 & 10 \\
\hline & カゼイン & 9 & 9 & 9 \\
\hline & SBR ラテックス & 13 & 13 & 8 \\
\hline \multirow{10}{*}{ 铗 } & 白 紙 光 沈 & 42.0 & 51.0 & 51.3 \\
\hline & 印刷 光 沢 & 64.9 & 66.8 & 67.5 \\
\hline & 白色度 & 86.8 & 87.4 & 87.4 \\
\hline & ドライ強度 & 3.8 & 3.0 & 3.8 \\
\hline & ウェット強度 & 5.0 & 3.0 & 4.8 \\
\hline & K \& N イ インク受理性 (\%) & 10.1 & 14.8 & 15.3 \\
\hline & 吸水着肉性 & 3.7 & 3.5 & 4.0 \\
\hline & インクセット & 4.0 & 4.0 & 4.8 \\
\hline & 糊 付 け性 （5点法） & 4.0 & 4.0 & 5.0 \\
\hline & ブリスターパック適性 & 4.0 & 4.0 & 5.0 \\
\hline
\end{tabular}

5 点法： 5 (優) 1(少)

配合はいずれもラテックスーカゼインのコバイン ダー系を用いた。

配合 $\mathrm{A} は$ 顔料として代表的な無機顔料である一級ク レイのみ(100 部)を用いた基準配合である。配合 B は 一級クレイの一部 (10 部) をプラスチックピグメント に代替した有機顔料併用配合である。配合 C は同様に 一級クレイの一部（10 部）をバインダーピグメントラ テックスに代替した配合である。配合Cではバイン ダーピグメントラテックスにバインダー機能があるこ とから通常のバインダーラテックスを減量した（13 部 $\rightarrow 8$ 部）点に大きな特徵がある。

有機顔料であるプラスチックピグメント，あるいは バインダーピグメントラテックスを用いた配合 $\mathrm{B}$ およ び配合Cでは一級クレイのみを用いた配合 $\mathrm{A} に$ 比較し て高い白紙光沢が得られた。また白色度も同様に向上 した。すなわち，プラスチックピグメントおよびバイ ンダーピグメントラテックスのいずれも有機白色顔料 としての機能を発現した。

表面強度はプラスチックピグメントを用いた配合 B では配合 $\mathrm{A} に$ 比較してドライ強度，ウェット強度のい ずれも低下した。プラスチックピグメントは一級クレ 亿に比較して比容積が大きい（比重が小さい）ため単 位重量あたりのバインダー所要量が多くなる。このこ とが表面強度の低下をもたらしたものである。 
表 2 塗工紙作成条件および評価方法

(塗工板紙作成条件)

原紙：高級白板紙原紙 $\left(200 \mathrm{~g} / \mathrm{m}^{2}\right)$

塗料濃度: $41 \%$

塗工：ワイヤーバー

塗 工量: $16 \mathrm{~g} / \mathrm{m}^{2}$

乾 燥: 熱風オーブン, $150^{\circ} \mathrm{C}, 20$ 秒

水処理: $3 \% \mathrm{ZnSO}_{4}$

カレンダー：テスト用スーパーカレンダー $100 \mathrm{~kg} / \mathrm{cm}, 60^{\circ} \mathrm{C}$

(評価方法)

白紙光沢： $75^{\circ}-75^{\circ}$ 鏡面光沢

印刷光沢：RI テスター (明製作所製) にてオフセットインク（東洋インキ TKU-70 G 藍）を印刷し， 1 日 後に光沢測定

白色 度: ハンター白色度計

ドライ強度：RI テスターにてピッキングテスト用インク (DIC，TV-22）を 4 回重ね刷りし，ピックの発 生度合を判定

ウェット強度：RI テスターにて，モルトンロールで水付着後ピッキングテスト用インク (DIC, TV-18) を印刷し，ピックの発生を判定

$\mathrm{K} \& \mathrm{~N}$ インク受理性：K＆N インクを塗布し，2 分後に拭き取り，白色度を測定，白色度低下率（\%)

吸水着肉性：RI テスターにてオフセットインク (東洋インキ TKU-70 G 墨) を練った後, ゴムロールと金 属ロールをわずかに離し，ロール間に水を流して印刷，インクの濃さを判定

インクセット：RI テスターにてオフセットインク (東洋インキ TKU-70 G 藍) を印刷後, 印刷面にコート

紙を重ねてゴムロールに圧着, インクのコート紙への転写濃度により判定, セット早いものが優

糊付け性： $35 \mathrm{~mm} \times 120 \mathrm{~mm}$ のサンプル紙片の塗工面にサックマシン用糊を塗布（厚さ $0.1 \mathrm{~mm}$, 幅 5 $\mathrm{mm}$, 長さ $50 \mathrm{~mm}$ ) した後, $25 \mathrm{~mm} \times 90 \mathrm{~mm}$ のサンプル紙片の裹面を糊面に接して重ね圧着する。16 時間後に糊面を剝がし, 破壞状態を判定する。紙層破壊するものが優, 塗工層ないしは荃工層表面で 剝がれるものが劣

ブリスターパック適性：ブリスターパック用ニス（荒川塗料ブリスターパック用ニスNo.11）をレジュー サーにて希釈し, サンプル塗工紙面に塗布して, $120^{\circ} \mathrm{C}$ で乾燥する。サンプルを $4 \mathrm{~cm} \times 4 \mathrm{~cm}$ に切り, 同一の大きさのブリスターパック用塩化ビニールシートを重ねる。電動ヒートシーラーにより熱融着 する。試験片と塩化ビニールシートを剥離して破壊状態を判定する。紙層破壊するものが優, 塗工層 ないしは塗工層表面で剝がれるものが劣

サンプルは白紙および印刷後のサンプルを用いる。

一方，バインダーピグメントラテックスを用いた配 合Cでは, 通常のバインダーラテックスを減量したに もかかわらず配合 $\mathrm{A}$ と同等のドライ強度およびウェッ 卜強度を示した。バインダーピグメントラテックスの 特殊な二層構造に由来するバインダー機能の発現が示 された。

塗工層表面の空隚の多寡を示す $\mathrm{K} \& \mathrm{~N}$ インク受理 性は配合 $\mathrm{B}$, 配合 $\mathrm{C}$ のいずれも配合 $\mathrm{A}$ に比較して向上 し, 有機顔料の特徵の一つである塗工紙表面の細孔を 増大させる効果が示された。

さらに，バインダーピグメントラテックスを用いた 配合Cではオフセット印刷における湿し水付着後のイ
ンク受理性の代用特性である吸水着肉性も向上した。 また，塗工板紙が製函時に要求される糊付け性および ブリスターパック適性も向上した。

バインダーピグメントラテックスはプラスチックピ グメントと同様に有機顔料としての機能を有し, さら にバインダーとしての機能を有していることが確認さ れた。

バインダーピグメントラテックスの特性は次のよう に整理される。

（1）有機白色顔料の機能を保有し, 白紙光沢, 白色 度を向上させる。

（2）バインダー機能を保有し，通常のバインダーラ 
テックス配合量を減量できる。

（3）インク受理性を向上させる。

（4）糊付け性，ブリスターパック適性を向上させる。

\section{2 配合量の影響}

バインダーピグメントラテックスの配合量を変えて 塗工紙特性への影響を検討した。塗工原紙には上質紙 を用いた。

配合を表 3 に示した。表面強度を同一レベルとする ため, バインダーピグメントラテックスの増加と共に 通常のバインダーラテックスの配合量を減少させた。

配合材料の比重と配合量から算出した各配合物の容 積 $\left(\mathrm{cm}^{3}\right)$ と, その容積に対する換算バインダー比率 $(\mathrm{g} /$ $\left.\mathrm{cm}^{3}\right)$ を表 3 に示した。ここで, バインダーピグメント ラテックスの配合量の $50 \%$ がバインダーであるとし て各配合における換算バインダー量 $(\mathrm{g})$ を算出した。

いずれの配合においても換算バインダー比率はほぼ 一定であった。

図 2 に白紙光沢およびクレイの配向の程度を示す X

表 3 配合量の影響検討配合

\begin{tabular}{l|r|r|r|r}
\hline \multicolumn{1}{c|}{ 配 } & \multicolumn{1}{c|}{1} & \multicolumn{1}{c|}{2} & \multicolumn{1}{c|}{3} & \multicolumn{1}{c}{4} \\
\hline 一級クレイ & 100 & 90 & 80 & 70 \\
$\begin{array}{l}\text { バインダーピグメン } \\
\text { トラテックス }\end{array}$ & 0 & 10 & 20 & 30 \\
カゼイン & 9 & 9 & 9 & 9 \\
$\mathrm{SBR}$ ラテックス & 13 & 8 & 4 & 0 \\
\hline \begin{tabular}{l} 
配合物容積 $\left(\mathrm{cm}^{3}\right)$ \\
\hline 換算バインダー量
\end{tabular} & 58.5 & 59.3 & 61.0 & 62.7 \\
\hline $\begin{array}{r}(\mathrm{g}) \\
\text { 換算バインダー比率 } \\
\left(\mathrm{g} / \mathrm{cm}^{3}\right)\end{array}$ & 0.367 & 0.371 & 0.377 & 0.383 \\
\hline
\end{tabular}

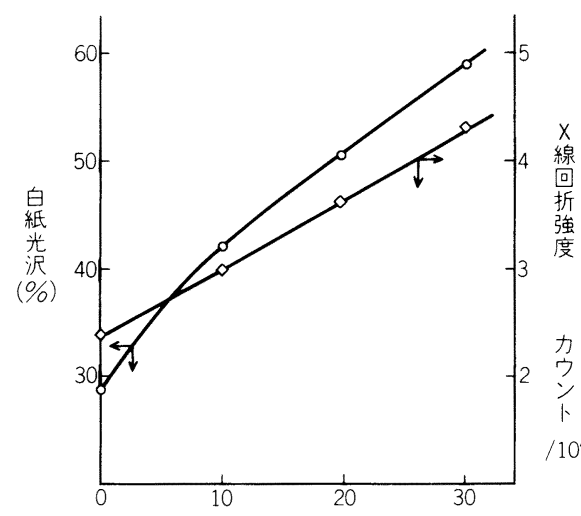

バインダーピグメントラテックス

配合量(部)

図 2 白紙光沢およびX線回折強度

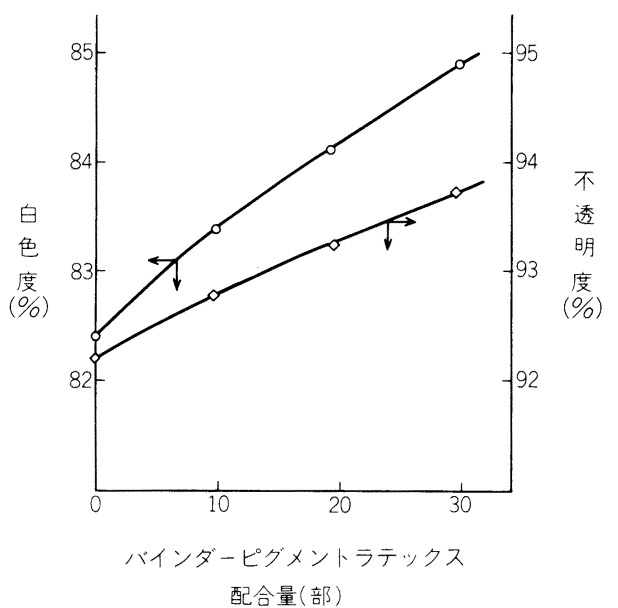

図 3 白色度および不透明度

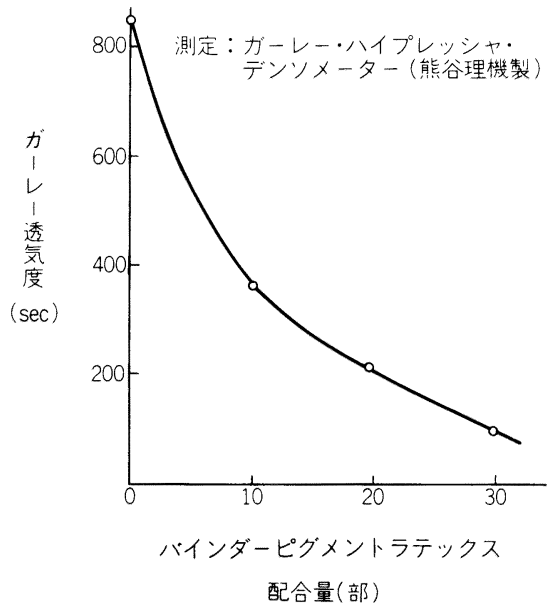

図 4 ガーレー透気度

線回折強度を示した。バインダーピグメントラテック スの配合によりクレイの配向が向上し，それが白紙光 沢の向上に寄与しているとみられる。

図 3 には白色度および不透明度を, 図 4 にはガー レ一透気度を示した。白色度や不透明度の向上には有 機顔料としての本来的な機能と共に，透気度の向上に みられる塗工層の空吵の増加による効果もあるといえ る。

一方，図 5 に示した $\mathrm{K} \& \mathrm{~N}$ インク受理性および吸 水着肉性の結果も，バインダーピグメントラテックス の配合が塗工層の空隚の増加をもたらしていることを 示唆している。

写真 2，3 に示した塗工層表面の走査型電子顕微鏡 写真によっても，バインダーピグメントラテックスの 配合により塗工層の空吵が増加していることが確認さ 


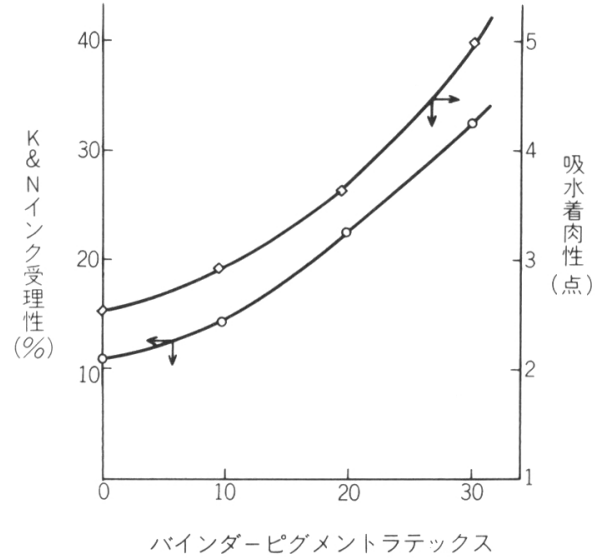

配合量(部)

図 5 インク受理性

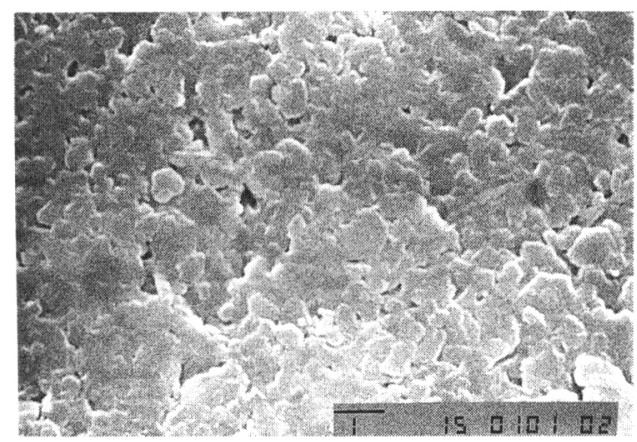

写真 2 クレイ単独配合（配合 1 ）の塗工層表面

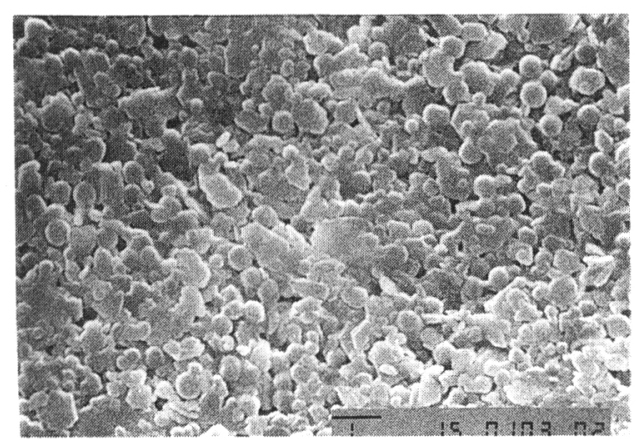

写真 3 バインダーピグメントラテックス 20 部配 合（配合 3 ）の塗工層表面

れた。

写真 2 はバインダーピグメントラテックスを含まな い一級クレイ単独配合の塗工層表面であり, 表面の空 吵は少なく, 一方, 写真 3 はバインダーピグメントラ テックスを 20 部用いた配合の塗工層表面であり空陌 が多かった。

バインダーピグメントラテックスの配合により空陌
の多い塗工層構造をとることが，インク受理性を向上 させていると共に糊付け性やブリスターパック適性も 向上させているとみられる。

糊付け性やブリスターパック適性には, 塗工層の強 度が強いことと糊やブリスターパックニスが塗工層内 に浸透し，投錨効果を示すことが必要である。バイン ダーピグメントラテックスを用いた配合は，十分な強 度と糊やブリスターパックニスが浸透し易い微細な細 孔を持った塗工層構造をもたらしているために，優れ た糊付け性やブリスターパック適性が得られたといえ る。

\section{4. 実機適用例}

バインダーピグメントラテックスの使用により塗工 紙物性が大幅に向上することから，塗工板紙分野では その使用が増大している。

以下に実機適用例を紹介する。

\section{1 一般塗工板紙への適用}

塗工板紙分野でバインダーピグメントラテックスが 使用されているのは，その白紙光沢向上効果とブリス ターパック適性向上効果に依るところが大きい。

表 4 および図 6 にバインダーピグメントラテックス を 5 部および 10 部使用した実機適用例の配合と得ら れた塗工板紙の評価結果を示した。

実機塗工においても白紙光沢, 白色度の向上が確認 された。また，通常のバインダーラテックスを減量し

表 4 バインダーピグメントラテックスの 実機適用例

\begin{tabular}{|c|c|c|c|c|}
\hline & & $\begin{array}{l}\text { 従来 } \\
\text { 配合 }\end{array}$ & 改良-1 & 改良-2 \\
\hline \multirow{4}{*}{ 配 } & 一級クレイ & 35 & 33 & 32 \\
\hline & 二級クレイ & 20 & 19 & 18 \\
\hline & 国産クレイ & 25 & 23 & 21 \\
\hline & 炭酸カルシウム & 20 & 20 & 19 \\
\hline \multirow[t]{3}{*}{ 合 } & $\begin{array}{l}\text { バインダーピグメントラテ } \\
\text { ックス }\end{array}$ & 0 & 5 & 10 \\
\hline & カゼイン & 6 & 6 & 6 \\
\hline & SBR ラテックス & 14 & 12 & 9 \\
\hline \multirow{5}{*}{$\begin{array}{l}\text { 評 } \\
\text { 価 } \\
\text { 結 } \\
\text { 果 }\end{array}$} & 白 色 度 & 71.1 & 71.9 & 72.3 \\
\hline & 印刷 光 沢 （\%) & 78.7 & 82.7 & 85.6 \\
\hline & K \& N インク受理性 (\%) & 24.3 & 28.5 & 29.2 \\
\hline & ドライ強度（５点法） & 5.0 & 5.0 & 5.0 \\
\hline & ウェット強度 & 5.0 & 5.0 & 5.0 \\
\hline
\end{tabular}

コート白ボール $310 \mathrm{~g} / \mathrm{m}^{2}$, エアナイフコーター, 塗工量 $15 \mathrm{~g} / \mathrm{m}^{2}$, 水処理, グロスカレンダー仕上げ 


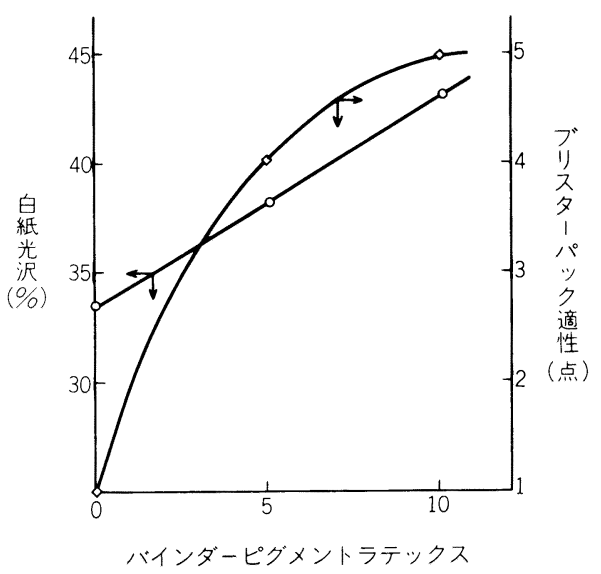

配合量(部)

図 6 実機エアナイフコーター塗工品の白紙光沢と ブリスターパック適性

ても十分な強度を維持することができた。さらにイン ク受理性や印刷光沢も向上した。これらの効果はバイ ンダーピグメントラテックスの配合量を増加すること により増大した。

バインダーピグメントラテックス配合の特長の一つ であるブリスターパック適性向上効果は図 6 のように 顕著であり，わずか 5 部の配合でも大幅な改善がみら れた。

\section{2 グラビア印刷用途への適用}

バインダーピグメントラテックスの使用により，塗 工紙表面の平滑性が向上することがその白紙光沢向上 効果から予期される。叙工紙表面の平滑性が印刷適性 の支配的要因となるグラビア印刷において網点欠落の 改善に有効となることが期待できる。

表 5 には塗工板紙でのグラビア印刷用途への適用結 果を示した。

バインダーピグメントラテックスを用いた改良配合 では触針式表面粗さ計による Ra（中心線平均粗さ）が $1.0 \mu \mathrm{m}$ から $0.6 \mu \mathrm{m}$ に改善され, 塗工板紙表面の平滑 度が向上した。

印刷局式グラビア印刷適性試験機を用いて網グラビ ア版で印刷を行い網点欠落（スペックル）の発生度合 を判定したが，改良配合では網点欠落が著しく減少し グラビア印刷適性が向上した。

\section{3 強光沢塗工板紙への適用}

バインダーピグメントラテックスの配合量を大幅に 増加することにより, 極好高い白紙光沢と印刷光沢 を得な例を表 6 に示した。

バインダーピグメントラテックスを 35 部と大量に
表 5 グラビア印刷用途への適用

\begin{tabular}{|c|c|c|c|}
\hline & & 従来配合 & 改良配合 \\
\hline \multirow{4}{*}{ 配 } & 一級クレイ & 30 & 25.5 \\
\hline & 二級クレイ & 30 & 25.5 \\
\hline & 国産クレイ & 30 & 25.5 \\
\hline & 炭酸カルシウム & 10 & 8.5 \\
\hline \multirow[t]{3}{*}{ 合 } & $\begin{array}{l}\text { バインダーピグメントラテ } \\
\text { ックス }\end{array}$ & 0 & 15 \\
\hline & カゼイン & 7 & 7 \\
\hline & SBR ラテックス & 13 & 6 \\
\hline \multirow{5}{*}{$\begin{array}{l}\text { 評 } \\
\text { 価 } \\
\text { 結 } \\
\text { 果 }\end{array}$} & 白紙 光 沢 （\%) & 40.2 & 49.8 \\
\hline & 白色 度 (\%) & 75.8 & 76.9 \\
\hline & K \& N インク受理性 (\%) & 21.2 & 31.2 \\
\hline & 中心線平均粗さ $\mathrm{Ra}^{* 1}(\mu \mathrm{m})$ & 1.0 & 0.6 \\
\hline & グラビア印刷適性 ${ }^{* 2}$ ( 5 点法) & 3.0 & 5.0 \\
\hline
\end{tabular}

*1 : 触針式表面粗さ計 (小坂研究所製) にて測定

*2: 印刷局式グラビア印刷適性試験機 (熊谷理機製) にて網グラビア版で印刷し，網点欠落（スペッ クル）の発生度合を判定，5（少）１（多)

表 6 強光沢塗工板紙への適用例

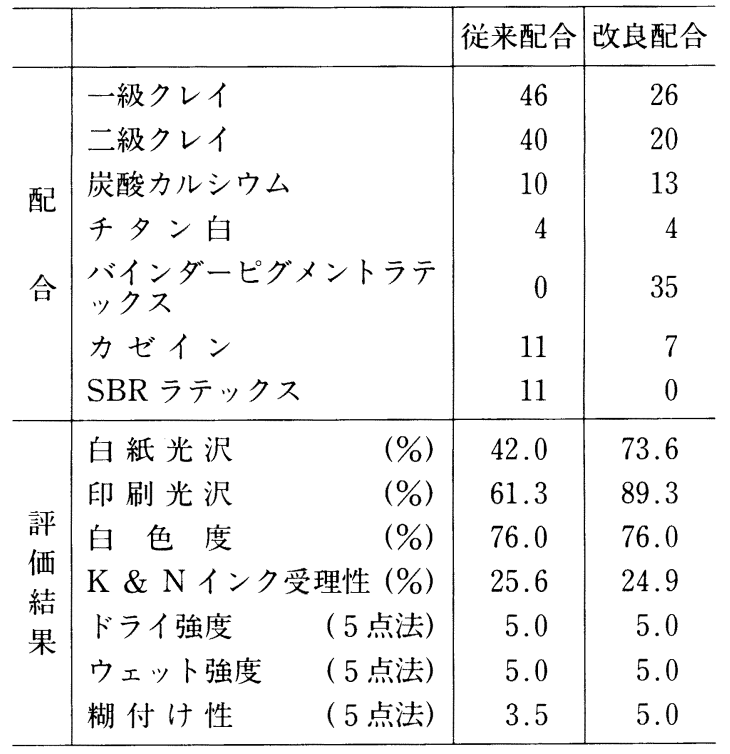

コート白ボール $310 \mathrm{~g} / \mathrm{m}^{2}$, エアナイフコーター

塗工量 $15 \mathrm{~g} / \mathrm{m}^{2}$, 水処理, グロスカレンダー仕上げ

用いて，通常のバインダーラテックスを全く使用せず， さらにコバインダーのカゼインも減量した点に配合上 の大きな特徴がある。

本例では 70\%超の白紙光沢と $90 \%$ 近い印刷光沢が 得られた。

このように，極めて高い白紙光沢と印刷光沢が得ら 
れるため, 塗工板紙で通常行われる印刷後の二ス引き 処理を行わなくても十分な光沢となる。二ス引き処理 をした塗工板紙表面は一般的にインク受理性が失われ るため, 二ス引き後の面に印字等をすることは困難と なる。

本例の強光沢塗工板紙ではニス引き処理をすること 無く十分な光沢が得られ，かつインク受理性も保持し ていることから, 印字を必要とする容器などに使用さ れている。

\section{4 塗エコストの適正化}

バインダーピグメントラテックスの使用はプラス チックピグメントの使用に比較して，通常のバイン ダーラテックスを減量できることから塗工コスト上は 有利である。しかし，一般の無機顔料より高価格の合 成高分子の配合量が増加するため，無機顔料のみを用 いた通常の配合に比較して塗工コストは上昇する。実 用配合においてはコスト上昇を抑えることが重要であ る。

バインダーピグメントラテックスの使用に伴う塗工 コストの上昇は, 無機顔料組成の変更や塗工量の低減 により抑制することができる。

表 7 には高価格な無機顔料であるチタン白の使用を やめることにより塗工コストの上昇を抑えた例を示し

表 7 チ夕ン白代替によるコスト低減例

\begin{tabular}{|c|c|c|c|}
\hline & & 従来配合 & 改良配合 \\
\hline \multirow{7}{*}{ 配 } & 一級クレイ & 35 & 35 \\
\hline & 二級クレイ & 47 & 40 \\
\hline & 炭酸カルシウム & 10 & 15 \\
\hline & チタン白 & 8 & 0 \\
\hline & $\begin{array}{l}\text { バインダーピグメントラテ } \\
\text { ックス }\end{array}$ & 0 & 10 \\
\hline & カゼイン & 6 & 6 \\
\hline & SBR ラテックス & 14 & 9 \\
\hline \multirow{8}{*}{$\begin{array}{l}\text { 評 } \\
\text { 価 } \\
\text { 結 } \\
\text { 果 }\end{array}$} & 白紙光 沢 （\%) & 40.5 & 49.7 \\
\hline & 印 刷 光 沢 & 64.8 & 72.5 \\
\hline & 白 色 度 （\%) & 77.9 & 77.5 \\
\hline & K \& N インク受理性（\%) & 21.0 & 24.7 \\
\hline & 吸水着肉性 （5 点法） & 4.0 & 5.0 \\
\hline & ドライ強度（ 5 点法) & 5.0 & 5.0 \\
\hline & ウェット強度 （ 5 点法 $)$ & 5.0 & 5.0 \\
\hline & ブリスターパック適性 & 1.0 & 4.8 \\
\hline & 塗 料 コ スト 比 & 100 & 97 \\
\hline
\end{tabular}

コート白ボール $310 \mathrm{~g} / \mathrm{m}^{2}$, エアナイフコーター

塗工量 $15 \mathrm{~g} / \mathrm{m}^{2}$, 水処理, グロスカレンダー仕上げ
た。

本例では従来配合において白色度を向上させる目的 でチタン白を用いていたが，主として白紙光沢とブリ スターパック適性の改善を目的としてバインダーピグ メントラテックスの適用が検討された。

配合から高価格なチタン白を無くすことによりバイ ンダーピグメントラテックスを用いた改良配合では塗 料コストは上昇せず，かえって若干低下させることが できた。

チタン白を無くしたことにより低下する白色度は， バインダーピグメントラテックスの配合による白色度 向上効果と炭酸カルシウムの増量により補填すること ができた。

本例では，目的とした白紙光沢とブリスターパック 適性の改善も十分に行うことができた。

表 8 および図 7 にサチン白代替による例を示した。 サチン白は白色度および白紙光沢の改善に有効な合 成無機顔料であるが，バインダー所要量が多いという 欠点がある。

白紙光沢の改善を目的とした本例ではサチン白に替 えてバインダーピグメントラテックスを用い，さらに 白色度, 白紙光沢を保持, 向上させるために二級クレ イに替えて一級クレイを使用した。また，バインダー 所要量の多いサチン白を使用しないことからバイン ダー量を減少させた。

サチン白を含む従来配合ではバインダーラテックス を 18 部使用していたが, サチン白に替えてバインダー ピグメントラテックスを用いた改良配合では，バイン ダーピグメントラテックスの配合量の $50 \%$ がバイン ダ一機能を有しているとして算出した換算バインダー ラテックス量を 14 部とした。

従来配合での塗工量は $16 \mathrm{~g} / \mathrm{m}^{2}$ であったが，同一塗

表 8 サチン白代替および塗工量低減によるコス 卜低減検討配合

\begin{tabular}{|c|c|c|c|c|}
\hline & & 従来 & 改良- & 改良-2 \\
\hline \multirow{5}{*}{ 配 } & 一級クレイ & 0 & 25 & 23.6 \\
\hline & 二級クレイ & 25 & 0 & 0 \\
\hline & 国産クレイ & 50 & 50 & 47.2 \\
\hline & 炭酸カルシウム & 15 & 15 & 14.2 \\
\hline & サチン白 & 10 & 0 & 0 \\
\hline \multirow[t]{3}{*}{ 合 } & $\begin{array}{l}\text { バインダーピグメントラテ } \\
\text { ックス }\end{array}$ & 0 & 10 & 15 \\
\hline & カゼイン & 6 & 6 & 6 \\
\hline & SBR ラテックス & 18 & 9 & 6.5 \\
\hline
\end{tabular}



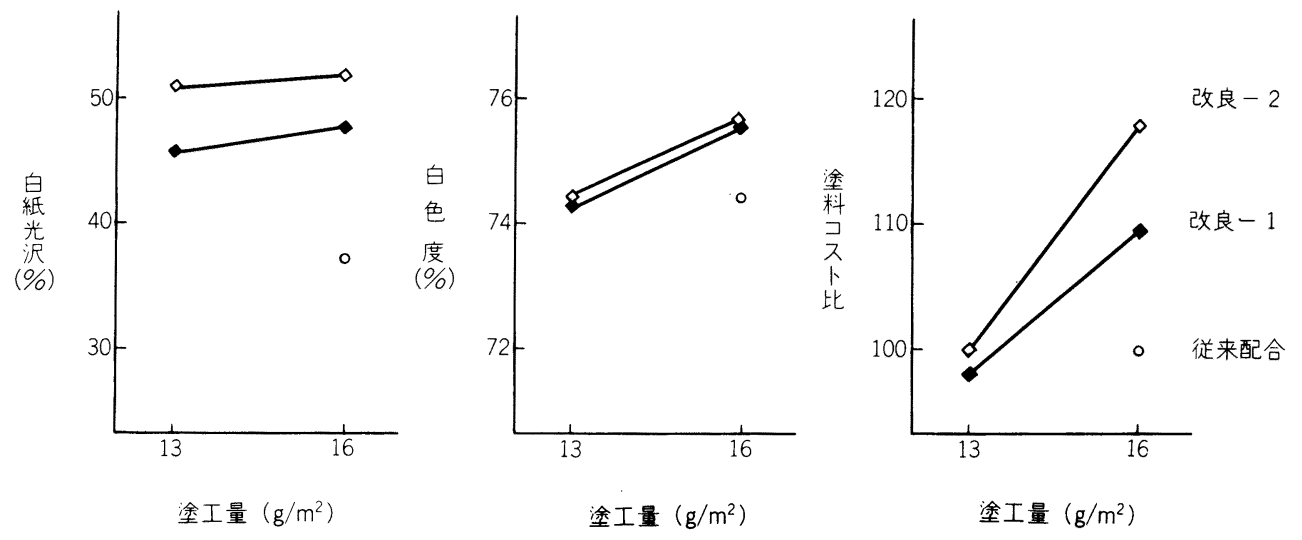

図 7 サチン白代替, 塗工量低減による塗工コスト低減の効果

工量での改良配合では白紙光沢, 白色度のいずれも大 幅に改善された。しかし，塗料コストの増加により塗 エコストが上昇した。

本例では白色度の改善は要請されていなかったため, 塗工量の低減による塗工コストの低減をはかった。塗 工量を $16 \mathrm{~g} / \mathrm{m}^{2}$ から $13 \mathrm{~g} / \mathrm{m}^{2}$ に低下させることによ り塗工単位面積当たりの塗料コスト，すなわち塗工コ ストは従来配合 $\left(16 \mathrm{~g} / \mathrm{m}^{2}\right)$ と同等となった。塗工量を 減少しても目的とした白紙光沢の向上は得られた。ま た, 塗工量の減少により白色度は低下したが従来配合 $\left(16 \mathrm{~g} / \mathrm{m}^{2}\right)$ のレベルを維持することができた。

\section{5. ま と め}

特殊な二層構造を有するバインダーピグメントラ テックスは白紙光沢, 白色度などの光学的特性の向上 をもたらす有機白色顔料としての機能とバインダーラ テックスとしての接着機能を併せ持っている。

バインダーピグメントラテックスの配合においては 通常のバインダーラテックスの配合量を減少すること ができる。

バインダーピグメントラテックスの使用により，イ ンク受理性や糊付け性, ブリスターパック適性が向上 する。
バインダーピグメントラテックスの使用により塗工 紙物性が向上することから，特に塗工板紙分野でその 使用が增大している。

実機適用においては白紙光沢やブリスターパック適 性の改善と共にグラビア印刷適性の改善も得られた。 また, バインダーピグメントラテックスを大量に配合 することにより，極めて高い白紙光沢と印刷光沢を 持った塗工板紙が得られた。

バインダーピグメントラテックスは合成高分子であ るため塗工コストの増加をもたらすが，プラスチック ピグメントに比較すると通常のバインダーラテックス を減量できるため塗工コストの増加は抑制される。

実用配合においては使用する無機顔料の配合変更や 塗工量の低減により塗工コストの増加をさらに抑制す ることができた。

\section{参考文献}

1) E. J.Heiser, A.Shand: Tappi, 56 (1), 70 (1973)

2) E.J.Heiser, A.Shand: Tappi, 56 (2), 101, (1973)

3) B.Alince, P.Lepoture : Tappi, 63(5), 49, (1980)

4）関矢正良, 石塚敏郎, 原田幸一, 宮本健三: 接着, 28, (11), 505, (1984) 